\title{
The impact of modular designs on new product development outcomes: The moderating effect of supply chain involvement
}

\begin{abstract}
Purpose: This study investigates impacts of product modularity and multi-skill employees on new product development (NPD) outcomes and explores the moderating effect of supply chain involvement.

Design/methodology/approach: We used data collected from 317 manufacturers to empirically examine the conceptual model and conducted hierarchical regression analysis to test the hypotheses.
\end{abstract}

Findings: The results reveal that product modularity significantly improves NPD outcomes. The relationship between product modularity/multi-skill employees and NPD outcomes is strengthened when the level of supplier involvement is high, while the relationship between multi-skill employees and NPD outcomes is weakened when the level of customer involvement is high.

Research limitations: First, this study only focuses on product modularity and multi-skill employees as two types of modular designs. Second, the inter-relationship between modular designs and supply chain involvement might be contingent. Third, we use cross-sectional data that cannot reflect causal effects of modularity on NPD outcomes.

Originality/value: The findings contribute to the understanding of the alignment between modular designs and supply chain involvement considering NPD outcomes. This study also contributes to the concept of modularity by identifying multi-skill employees as a type of modular design.

Keywords: product modularity; multi-skill employees; customer involvement; supplier involvement; new product development.

\section{Introduction}

As product life cycles shorten and the demand market becomes heterogeneous, firms now face intensified competition in new product development (NPD). To outperform the competition, firms need to improve product development lead time, reduce the costs of manufacturing, enhance product quality, improve customer satisfaction, and promote market performance. NPD is characterized by high levels of complexity of product configurations and tasks. To 
address these challenges, increasing numbers of firms are adopting modular designs to decrease complexity and increase flexibility (Vickery et al., 2016, Hallgren and Olhager, 2009).

Modularity refers to "the practice of using standardized modules so that they can be easily reassembled/rearranged into different functional forms, or shared across different product lines" (Tu et al., 2004). The key to modularity is minimizing the degree of coupling among different functional modules (Cabigiosu and Camuffo, 2017, Tu et al., 2004). As a general system concept, modularity can be applied in a wide range of organizational contexts. The application of modularity in product design is most common. Product modularity entails the decomposition of a complex product design into independent modules and the capability to adapt to new configurations readily. It is an effective NPD strategy and can be used to launch new products frequently, quickly, and efficiently. For instance, General Motors implemented the Yellowstone program, which applied modular designs in small car production, to achieve highly efficient production systems (Tu et al., 2004). Dell Computers used modular components that can be flexibly mixed, assembled, and packaged into different configurations in its product lines to simplify design processes and reduce lead time (Ro et al., 2007). Other studies have explored modular designs in organizations (Baldwin and Clark, 1997, Brusoni, 2016), including task division (Lee and Berente, 2012), knowledge development (Brusoni et al., 2001), and process architecture (Colfer, 2007, Vickery et al., 2016). In these cases, knowledge, tasks, and processes are regarded as complex artefacts that can be decoupled into independent modules to reduce the complexity of product design and team coordination in NPD (Brusoni, 2016). With the exception of Tu et al. (2004), the literature has largely neglected the application of modularity in human resources (De Blok et al., 2013). Employees play critical roles in NPD, such as forming problem-solving teams and performing specific tasks. Modular designs in human resources are achieved by training employees with multi-skills to conduct different functional tasks (Ahmad and Schroeder, 2003). Such training allows them to be independent and to be removed or replaced when necessary, which permits a high degree of decentralization and efficient use of human resources (Colfer, 2007). Through incorporating two types of modular designs (i.e., product modularity and multi-skill employees), this study shows how to reduce complexity in the product and human resource design (Colfer, 2007, Campagnolo and Camuffo, 2009).

A large body of literature indicates the need to consider supply chain designs in addition to product and process designs in NPD (Pashaei and Olhager, 2015, Nepal et al., 2012, Petersen et al., 2005, Wang et al., 2018). Involving suppliers and customers in NPD has been viewed as an important approach for a manufacturer to obtain external resources and knowledge (e.g., 
Lau, 2011b, Salvador and Villena, 2013, Peng et al., 2014). A wealth of literature has demonstrated the positive impact of supplier and customer involvement on NPD performance (e.g., Salvador and Villena, 2013, Peng et al., 2013, Liao et al., 2010, Knudsen, 2007, Lau, 2011a).

However, researchers have debated how modular designs and supply chain involvement are aligned (Furlan et al., 2014, Caridi et al., 2012, Davies and Joglekar, 2013, Pashaei and Olhager, 2015, Pero et al., 2010). One strand of research suggests that modular designs need to be accompanied by loose supply chain architecture because of the low level of interactions between supply chain partners (Cabigiosu and Camuffo, 2012, Furlan et al., 2014). This perspective is built upon the "mirroring" hypothesis proposed by Sanchez and Mahoney (1996) that "the [loosely coupled] standardized component interfaces in a modular product architecture provide a form of embedded coordination that greatly reduces the need for overt exercise of managerial authority to achieve coordination of development processes, thereby making possible the concurrent and autonomous development of components by loosely coupled organization structures." In other words, modular designs require less explicit coordination when firms rely on standardized and independent modules. This perspective emphasizes consistency regarding levels of modularity in different systems (Cabigiosu and Camuffo, 2012, Baldwin and Clark, 2000, Fine et al., 2005). Thus, modular designs should be in line with autonomous and loosely coupled supply chain features, while integral designs should be in line with cooperative and tightly connected supply chain features.

Another stream of research maintains that modular designs call for highly integrated supply chain architecture that is characterized by strong collaboration and high degrees of communication and involvement (Brusoni et al., 2001, Ro et al., 2007, Fine et al., 2005, Lau and Yam, 2005). Contrasting views suggest that the mirroring hypothesis is too simplistic and neglects the benefits brought by supply chain involvement (Hao et al., 2017, Lau and Yam, 2005, Colfer and Baldwin, 2016), which provides external knowledge for modular designs (Davies and Joglekar, 2013, Nepal et al., 2012, Mikkola, 2003). For instance, when the supplier is involved in solving technical problems during the product development phase, the focal firm could learn by doing or learn by failure and use this knowledge in product architecture or employee training (Mikkola, 2003). At the heart of the debate is whether firms can depend on independent and standardized modules in NPD with low involvement from supply chain partners or whether they need to leverage component-specific or architectural knowledge from external partners to better perform in modular designs (Brusoni et al., 2001, Takeishi, 2001, Baldwin and Clark, 2000). 
A more in-depth investigation of the role of supply chain involvement in the relationship between modular designs and NPD outcomes is therefore necessary (Fixson, 2007, Sorkun and Furlan, 2017). One gap is that previous studies do not compare different types of modular designs. In product architecture design, modularity involves reducing interdependencies among components within products, while in human resource architecture design, modularity entails decreasing interdependencies among employees. Another research gap is that studies focus only on the supplier side, few studies consider customer involvement. As suppliers and customers play different roles in NPD, their impacts may also differ. For example, suppliers offer component-specific recommendations, while customers provide their preferences in the design and production processes. By identifying two types of modularity and considering supplier and customer involvement simultaneously, this study reconciles contrasting perspectives on the mirroring hypothesis.

In summary, this study addresses an important research question: how do modular designs (i.e., product modularity and multi-skill employees) and supply chain involvement (i.e., supplier and customer involvement) interact to influence NPD outcomes? The study unfolds as follows. First, we review the relevant literature and propose research hypotheses. Then, we describe our research methodology and statistical analyses, and then show the results and conduct robustness tests. Finally, we draw conclusions and discuss the study's limitations and future research directions.

\section{Literature Review and Hypotheses Development}

\subsection{Modular designs}

Modular designs are created by decomposing a complex system structure into independent and standard subsystems that allow reconfiguration (Baldwin and Clark, 1997, Worren et al., 2002). Modularity can be regarded as the extent to which system components can be separated and reconfigured, and can be considered as a continuum ranging from integral to modular (Schilling, 2000). Modular product design is achieved by decoupling a complex product design into standardized components or modules (Davies and Joglekar, 2013). Product modularity undermines complexity in product designs, reduces interdependencies among components, enables concurrent module development, and facilitates flexible product configurations, thus allowing accelerated design and the introduction of a wide category of products (Vickery et al., 2013, Yin et al., 2014, Mikkola and Gassmann, 2003). Product modularity is omnipresent in manufacturing industries, including the automobile, electronics, automotive, machinery, and mechanical industries (Sorkun and Furlan, 2017, Kapoor, 2013). A rich body of literature has 
investigated product modularity in these industries. MacDuffie (2013) demonstrated antecedents and barriers to product modularity in the automobile industry using a case study. Cabigiosu and Camuffo (2012) empirically tested the relationship between product modularity and inter-organizational relationships in the air conditioning industry. Ernst (2005) investigated the impact of product modularity on collaboration in the semiconductor industry. Lau and Yam (2005) found that product modularity in the electronics industry requires close supply chain coordination.

The philosophy of modular designs can be applied to human resource management. Traditionally, each employee is trained with a specialty, and in most cases, they are irreplaceable. Employees are highly interdependent and need frequent coordination to perform tasks, and it is particularly difficult to reorganize in situations when task requirements change. The application of modular designs in human resources may overcome this shortcoming. Tu et al. (2004) proposed that dynamic teaming can reorganize teams quickly in response to changes in product design processes. Appelbaum et al. (2000) suggested that modular teams composed of multi-skill employees can reduce interdependence and coordinate more easily and are more likely to achieve autonomy. In this study, modular design in human resources is captured by the degree to which employees are trained with multi-skills to carry out tasks independently. We envisage multi-skill employees as dynamic modules with diverse skills that combine advantages of standardization and flexibility. Having multi-skill employees allows firms to create and reconfigure problem-solving teams in response to changes in product and supply chain designs and to high levels of uncertainty and complexity in NPD tasks (Akgün et al., 2008, Tien-Shang Lee, 2008). Nokia used a modular structure for human resource architecture (Gratton and Ghoshal, 2005), and their employees can be reused and reconfigured in different teams to accommodate changing requirements.

Product modularity and multi-skill employees thus represent two types of modular designs in firms. The former corresponds to modularity in product design, while the latter corresponds to modularity in workforce design; both have the objectives of increasing flexibility and reducing interdependence in organizations.

\subsection{The effect of product modularity on NPD outcomes}

Product modularity, as a modular product architecture design, is the use of standardized components that can be decoupled and reconfigured into a variety of products according to specific requirements (Ahmad et al., 2010). Separability and combinability are two major features of product modularity (Cabigiosu and Camuffo, 2017). Product modularity reduces 
the coupling and interdependence of components and facilitates the convenient recombination of components into a variety of products. The features are achieved through adopting standardized interfaces in product designs and creating interchangeable components in product platforms (Baldwin and Clark, 2000, Salvador and Villena, 2013, Cabigiosu et al., 2013). The potential benefits of product modularity include improving structural flexibility, enhancing product variety, improving product quality, shortening lead time, and achieving economies of scale (Worren et al., 2002, Jacobs et al., 2007, Danese and Filippini, 2010, Fixson, 2007, Mikkola and Gassmann, 2003).

Product modularity enables a manufacturer to achieve product success and market goals in NPD because of decoupled product functions, standardized modules, and various configurations (Danese and Filippini, 2010, Heim et al., 2012, Vickery et al., 2016). First, a modular product architecture facilitates task specification and independence (Sanchez and Mahoney, 1996). Because a product usually involves successive parts or components, the design of one part usually reacts to changes in other parts. For instance, in producing a car, the designs of the engine, the wheel, and the steel frame could be related to each other (Salvador and Villena, 2013). Modularity reduces chain reactions in manufacturing processes, making it easier to identify problems and to maintain, repair, and upgrade products. To this end, firms could develop a more reliable production system, improving product quality and reducing costs related to product changes and redesign (Danese and Filippini, 2010). Likewise, product modularity raises post-sale services to a higher level by enabling the simple and fast replacement of the faulty parts of a product (Tu et al., 2004). Moreover, as different modules can be designed and developed separately and concurrently, product modularity reduces the effort needed for the detailed designing, testing, and manufacturing of products, thus facilitating ease of manufacturing and shortening time to market (Danese and Filippini, 2010, Vickery et al., 2016).

Second, product modularity reduces design iterations and redundancy by applying common interfaces and using standardized modules (Salvador and Villena, 2013). Product components are shared across different product lines and assembly parts, and thus design efforts and inventory costs are greatly reduced (Sanderson and Uzumeri, 1997). By applying standardized process architecture across different departments and teams, modularity enhances coordination and eases the outsourcing of production to partners (Campagnolo and Camuffo, 2009, Worren et al., 2002). It also increases the visibility of a supply chain and the testability of products, and promotes the tracking and tracing system (Zhang et al., 2017). In this sense, 
product modularity reduces total costs and improves the conformance quality and efficiency of NPD.

Third, product modularity provides greater product variety and facilitates innovation, allowing a manufacturer to cope better with changing environments (Mikkola and Gassmann, 2003, Pil and Cohen, 2006, Vickery et al., 2016). Easy reconfigurations of modular components make it possible to satisfy diverse customer demands and hence to improve customer satisfaction and reap market profits. Moreover, product modularity shortens the time and reduces the efforts required to develop different product configurations, and it eases trial-anderror processes in NPD, leading to rapid incremental innovation (Danese and Filippini, 2013). Therefore, we propose (Figure 1):

H1. Product modularity is positively related to NPD outcomes.

======Insert Figure 1 about here======

\subsection{The effect of multi-skill employees on NPD outcomes}

Multi-skill employees can flexibly engage in diverse tasks and jobs (Atkinson, 1985). Firms with multi-skill employees can form NPD teams of employees with various types of functional expertise and a wide spectrum of knowledge to communicate and coordinate different tasks (Edmondson and Nembhard, 2009). Such firms can flexibly reconfigure NPD teams while avoiding high coordination costs and reducing vulnerability to uncertainties and risks (e.g., employee turnover and task changes). These NPD teams are characterized by a low level of interdependence among team members and a high level of flexibility.

The benefits of having multi-skill employees derive from decoupled team members, their ability to execute multiple tasks, and flexible configurations (Boxall and Steeneveld, 1999, Huo et al., 2016). First, through multi-skill training and job rotation, each employee will possess basic mechanic, problem-solving, and operational skills to manage different tasks (Barz and Kolisch, 2014). Hence, there will be a low level of interdependency among NPD team members (Cordery et al., 1991). Firms will not be vulnerable to employee absenteeism and turnover, which will maintain efficiency in NPD tasks and reduce the costs associated with workforce deployment (Kumar and Motwani, 1995).

Second, multi-skill employees can execute a variety of tasks. The division of NPD tasks among employees will be less complicated, and the speed to complete tasks will increase. Multi-skill employees are also more capable of sharing knowledge and coordinating with each other, as they know each other's strengths and skills (Tang et al., 2015, Appelbaum et al., 2000). This shared understanding can also help team members anticipate others' behaviors, reducing 
information searching efforts and improving coordination efficiency (Tang et al., 2015, Batt and Doellgast, 2005).

Third, multi-skill employees can adapt to different task requirements and respond to changing environments (Martinez-Sanchez et al., 2011, Salvador, 2007, Huo et al., 2016). With such employees, firms can quickly reshape their existing configurations of NPD teams or organize new teams for new requirements with no delay for extra training and recruitment (Batt and Doellgast, 2005). This rapid response to market demands will improve time to market, customer satisfaction, and return on investment performance. In addition, having multi-skill employees reduces team size, thus enhancing collaboration and information processing efficiency in teams (Wagner and Hoegl, 2006). Smaller teams with multi-skill employees can perform equivalent tasks while achieving better performance. Therefore, we propose the following:

H2. Multi-skill employees are positively related to NPD outcomes.

\subsection{The alignment between modular designs and supply chain involvement}

Understanding the relationship between modular designs and supply chain involvement lies in the modularity theory, which seeks to explain the boundaries and structures of firms (Sanchez and Mahoney, 1996, Baldwin, 2007). At the heart of this theory is the "mirroring" hypothesis (Colfer, 2007, Sanchez and Mahoney, 1996), which states that the architecture of interfirm relationships mirrors the corresponding product and human resource designs for the best alignment. In this study, a mirror emerges if the adoption of modular product design (human resource design) is aligned with loosely coordinated supply chain relationships (i.e., low supply chain involvement) and if the adoption of integral product and human resource design is matched with highly collaborative and coupled supply chain relationships (i.e., high supply chain involvement) (Fine et al., 2005). A number of studies empirically supported the mirroring theory (e.g., Schilling and Steensma, 2001, Fixson and Park, 2008, Cabigiosu and Camuffo, 2012, Brusoni et al., 2001). For instance, Hoetker et al. (2007) indicated that modular designs provide more autonomy for suppliers and that extensive supplier involvement becomes unnecessary. Lau et al. (2010b) found that modular designs correspond to loosely coordinated supply chains.

The reasons supporting the mirroring hypothesis are twofold. First, modular designs reduce information sharing for coordination needs (Hofman et al., 2017, Baldwin and Clark, 2000, Sorkun and Furlan, 2017). In modular product designs, specific technological and tacit knowledge are embedded within modules. Such knowledge encapsulation creates an 
"information hiding" effect that reduces the need for ongoing and interactive communication with suppliers and customers (Furlan et al., 2014), as multi-skill employees can work autonomously and make decisions based on local knowledge. In both cases, firms tend to rely on loose supply chain relationships (Furlan et al., 2014, Hoetker, 2006, Schilling and Steensma, 2001). However, if modular designs are embedded in extensively interactive supply chain relationships, firms may have to spend more time communicating knowledge about different modules, which hampers NPD efficiency. Second, the mirror provides operational benefits, such as improved efficiency, reduced errors, and better flexibility (Cheng, 2011, Worren et al., 2002, Gualandris and Kalchschmidt, 2013, Argyres, 1999). With loosely coupled supply chain relationships, firms can specialize in particular modules and even facilitate concurrent production (Sanchez and Mahoney, 1996), thus shortening NPD time and improving efficiency. The design of independent modules reduces design complexity and team cooperation difficulty, reducing product errors or task failure arising from complexity. Moreover, both modular designs and loosely coordinated supply chain relationships have the advantage of flexibility (Cheng, 2011, Worren et al., 2002), enabling firms to swiftly form new configurations to mitigate risks and satisfy customer requirements (Sorkun and Furlan, 2017).

However, many studies have criticized the mirroring hypothesis is a one-to-one perspective that is too simplistic and static (Furlan et al., 2014, Davies and Joglekar, 2013, Brusoni, 2016, Colfer and Baldwin, 2016, Sorkun and Furlan, 2017). Modular designs require close not loose relationships with supply chain partners for better alignment. For instance, Davies and Joglekar (2013) found that product modularity is associated with increased supply chain performance when combined with supply chain integration. Salvador and Villena (2013) indicated that modular design competence and supplier integration synergistically improve NPD performance. Colfer and Baldwin (2016) suggested that breaking the mirror can lead to better performance when firms face changing and complex external environments. Brusoni (2016) argued that modular designs do not necessarily lead to loose networks due to the need for problem-solving activities. In real cases, the "mirror" is often misted or even broken. For example, MacDuffie (2013) analyzed cases from two automobile producers (i.e., Ford and Hyundai) that adopted modular designs. While Ford expected product modularity to align with low coordination with suppliers initially, the practice failed and was abandoned. Hyundai developed integrative organizational processes with a critical supplier to lower costs and facilitate design innovation. Mikkola (2003) described the case of Chrysler, which adopted a modular design approach in its product development for the Jeep Cherokee with the supplier. The design failed in the beginning, as the suppliers did not understand some of the 
specifications. Later, Chrysler and the suppliers enhanced their level of interaction, which allowed both firms to develop a shared knowledge base of product design. These cases indicated that modularity should be synergized with close coordination and frequent interactions with supply chain partners.

Most criticism arises from the knowledge-based view, which suggests the importance of obtaining critical knowledge from suppliers and customers (Salvador and Villena, 2013, Davies and Joglekar, 2013, Kim and Anand, 2018). Effective modular designs need coupling and interactions with suppliers to ensure the extensive component-specific knowledge and information that are critical for identifying problems at the production stage, avoiding performance bottlenecks, and introducing successful product configurations (e.g., Salvador and Villena, 2013, Danese and Filippini, 2010, Wu and Ragatz, 2009, Brusoni, 2016). Moreover, NPD involves intensive innovative activities and novel technical systems that hinge upon the cooperative activities of firms in terms of close working relationships and increased information exchange with supply chain partners (Furlan et al., 2014, Hofman et al., 2017). While multi-skill employees can work independently, there is increasing need to involve supply chain partners to perform challenging tasks. Thus, the significance of intensive communication and coordination with supply chain partners explains why firms break the "mirror." In this study, we adopt the latter view to propose relationships between these activities.

Involving suppliers in NPD adds value to product modularity, which emphasizes product breakdown and standardization, and its performance depends on component and architectural design for decoupling modules and interfaces (Zirpoli and Camuffo, 2009, Mikkola, 2003). Given suppliers' specialized and tacit know-how of product designs, materials, and technologies, their early involvement facilitates joint decisions on the design of modular components and interfaces (Salvador, 2007, Zhang et al., 2017, Petersen et al., 2005). Suppliers can forecast technology trends, anticipate possible problems ahead, identify advantages and risks of product configurations, and conduct additional tests for potential problems for product specifications to achieve better product modularity performance (Danese and Filippini, 2013, Mikkola and Skjott-Larsen, 2004). In addition, a high level of product modularity facilitates the deployment and organization of tasks and the development of efficient processes, and it smooths operations for product and engineering design (Lau et al., 2010b, Mikkola, 2003, De Toni and Nassimbeni, 2003). Suppliers can more easily engage in the concurrent engineering of product modules, decreasing complexity coordination (Lau et al., 2010b, Salvador and Villena, 2013). 
Customer requirements are the starting point for modular product design. By involving customers in product design, firms can tailor the modular design to their specifications. When customers are engaged early in design processes, they can design modular components or combine existing modules for specific requirements (Zhang et al., 2014). Second, customers can share timely market knowledge with NPD teams and help them identify the best module designs, evaluate new product configurations, and conduct trial-and-error tests (Zhang et al., 2014). Third, in an uncertain environment, customer involvement helps manufacturers to improve forecasting accuracy and reduce risks by reconfiguring and adapting modules and components creatively (Priem and Swink, 2012). Thus, we propose the following:

$\mathrm{H} 3 \mathrm{a} / \mathrm{b}$. The positive relationship between product modularity and NPD outcomes is stronger when the level of supplier/customer involvement is high.

Multi-skill employees can effectively align with supply chain partners in NPD. Despite the independent and autonomous features of multi-skill employees, they will perform better if they detect external knowledge and learn new ways to perform tasks rather than focusing on the current breadth of skills (Camps et al., 2016). When involving suppliers or customers in NPD, multi-skill employees can identify, access, and tap into their knowledge. Moreover, they have the ability to absorb and integrate external knowledge into ideas and projects (Swan et al., 1999, Jansen et al., 2005). As such, when firms have employees with broad skills, they can take better advantage of supply chain involvement by integrating and re-shaping their knowledge, thus improving innovation and flexibility in NPD (Chang, 2007). As employees receive crossfunctional training and job rotations to obtain multiple skills, they obtain a broader view of their firms and are better able to engage in various internal and external tasks (Chang, 2007). They become more effective in conducting NPD tasks, such as product prototype development, product and process engineering, and product experimentation, and more responsive to uncertainty caused by technology and product changes. When suppliers are engaged in product design efforts, these employees can better manage inter-organizational activities, such as collaborative design and concurrent engineering, and build long-term relationships with suppliers (Mikkola, 2003). In this sense, multi-skill employees can take advantage of supplier involvement and achieve better NPD outcomes. Supplier involvement can also facilitate the organization of cross-functional teams composed of multi-skill employees to perform different NPD tasks (Ethiraj et al., 2008).

Following similar rationale, the moderating effect of customer involvement in the relationship between product modularity and NPD outcomes can be illustrated in two aspects. First, multi-skill employees can absorb knowledge from customers quickly and apply this 
knowledge in the development of new products (Swan et al., 1999). While knowledge from customers is unsystematic and scattered compared with that from suppliers, multi-skill employees can identify and assimilate the knowledge that is valuable (Chang, 2007). Based on their understanding of customer requirements, multi-skill employees can make changes and adapt to different tasks and processes. Second, when customers are involved in NPD, multiskill employees can understand their needs better and work more effectively with them in product co-design. They are also more willing to carry out new tasks and responsibilities, facilitating quick adaptation to customer requirements. Manufacturers can easily form flexible and dynamic teams to coordinate with customers without modifying their human resource base (Tu et al., 2004). In this way, multi-skill employees become a critical resource with a high level of customer involvement. Therefore, we propose the following.

H4a/b. The positive relationship between multi-skill employees and NPD outcomes is stronger when the level of supplier/customer involvement is high.

\section{Research Method}

\subsection{Data collection}

We used data from the third round of the High Performance Manufacturing (HPM) project to test our hypotheses (Schroeder and Flynn, 2002). The HPM is a large-scale survey collected in 2005-2007 in 10 countries (Austria, China, Finland, Germany, Italy, Japan, South Korea, Spain, Sweden, and the United States of America) across 3 industries (machinery, electronics, and transportation). The database was appropriate for testing our hypotheses because the manufacturing plants in these industries had sophisticated operations and supply chain practices, such as modularity and supply chain involvement (Danese and Filippini, 2013). Firms in these industries may produce both technically simple and complex products, providing sufficient variance to examine modularity (Vickery et al., 2016). Table 1 shows the sample profile by country and industry. The population data were obtained from each country's Bureau of Statistics.

\section{$======$ Insert Table 1 about here======}

The data collection process was conducted by a team of researchers in each country. The questionnaires were developed in English, translated into each local language, and then backtranslated into English for cross-checking. The research team selected the sample randomly from a master list of manufacturing firms in each country and solicited plant participation by contacting plant managers to state the project objectives, describe the questionnaire content, and offer prospective benefits. Upon agreement, a battery of questionnaires and instructions 
for administrating the survey were mailed to a coordinator at each plant, who then distributed each questionnaire to the designated respondents, collected the completed questionnaires, and mailed them back to the research team. To ensure the independence of the samples, only one plant was included in each of the manufacturing firms. In total, 317 responses were returned, yielding a response rate of $65 \%$.

Following Podsakoff et al. (2003), this study controlled and tested common method bias in several ways. In the design of survey procedures ex ante, we arranged for different respondents to respond regarding independent and dependent variables (Heim and Peng, 2010). In this way, we eliminated the influences of consistent motifs and social desirability tendency, which may create bias in the observed relationships. We also separated independent and dependent variables in the design of questionnaires, thus controlling the retrieval cues from the logical flow (Craighead et al., 2011). Statistical remedies were conducted ex post to test for common method bias. We first conducted Harman's one-factor analysis. The exploratory factor analysis (EFA) results showed five factors with eigenvalues greater than 1.0; the largest factor explained only $20.5 \%$ of the total variance. We then conducted confirmatory factor analysis (CFA) with a single factor. The fit indices (chi-square $(170)=1739.86, \mathrm{RMSEA}=0.21$, NNFI $=0.11, \mathrm{CFI}=0.20$, Standardized RMR $=0.19$ ) were not acceptable, indicating that the singlefactor model was not appropriate. Thus, common method bias was not an issue in this study.

\subsection{Measurement}

The measurement items were developed from the literature. The content validity of each measure was checked upon the design of the project through expert interviews. Product modularity, multi-skill employees, NPD outcomes, and supplier and customer involvement were measured using a 7-point Likert scale (Appendix).

Product modularity (PM) was a 3-item scale regarding common modules and product platforms in product design (Salvador and Villena (2013), (Danese and Filippini, 2013). The two most critical features for product modularity are standardized design and component sharing (Cabigiosu et al., 2013). The application of common modules captured standardization and the use of the product platform reflected inter-changeable components. Multi-skill employees (ME) was measured using four items that described the extent to which employees were cross-trained and obtained multiple skills. The items were adapted from Ahmad and Schroeder (2003). NPD outcomes (NPD) used five items to assess the market goal achievement and product design success of an NPD project (Heim et al., 2012). Two items (i.e., return on investment and customer satisfaction) captured market outcomes, and three items (i.e., time to 
market, ease of manufacturing, and product conformance quality) indicated the product design outcomes of an NPD project. Supplier involvement (SI) was measured with four items that evaluated the timing, degree, and nature of suppliers' involvement in an NPD project. Similarly, customer involvement (CI) was measured with a 4-item scale that assessed the timing, extent, and features of customers' involvement in an NPD project. The items were previously used by Mishra and Shah (2009), Salvador and Villena (2013), and Peng et al. (2014). These measures highlighted suppliers' and customers' early involvement, partnership, frequent consultation, and integral roles in product design. Supply chain involvement features the degree of coupling among firms. A low level of supply chain involvement indicates a loosely coupled supply chain relationship, while a high level signifies a closely integrated supply chain relationship. Similar operationalizations can be found in Caridi et al. (2012), Davies and Joglekar (2013), and Cabigiosu and Camuffo (2012).

We introduced project-, plant-, and industry-level control variables that may affect the dependent variables (Peng et al., 2014, Salvador and Villena, 2013, Mishra and Shah, 2009) to reduce the likelihood of endogeneity. At the project level, we controlled for team size, team expertise, project priority, product size, and manufacturing involvement. Team size was measured by the number of people involved in an NPD project. Because more team members are related to higher complexity and more obstacles in collaboration, team size might negatively influence NPD outcomes. Team expertise was measured as the percentage of team members with strong expertise, as a team with more technical skills is more likely to achieve project goals and gain product design success. Project priority was measured as the degree of importance of a project compared to others, which may affect NPD outcomes. Product size was measured as the number of parts in a product. Products with many components have greater task interdependence, which could lead to a modularized design and negatively affect NPD outcomes. Manufacturing involvement was measured by the degree of manufacturing function involved at early stages of NPD. Similar to the effects of supplier and customer involvement, manufacturing involved in NPD design can improve functional coordination and bring more knowledge to NPD processes.

At the plant and industry levels, we first controlled for continuous improvement, which was measured as the degree of continuous learning and improvement efforts. As firms with continuous improvement capability can effectively implement different processes, they are more likely to achieve expected NPD outcomes (Peng et al., 2013). We then controlled for demand variability and measured it as the extent to which customers' demands changed. The level of demand variability may be related to firms' decision to introduce the product and 
human resource modularity design (Danese and Filippini, 2013) and cause problems in NPD collaboration (Salvador and Villena, 2013). A source of variation comes from firm size, measured as the total number of employees. A large firm can provide more resources to implement NPD projects. We further controlled the supply chain competence of the focal firm compared with its competitors. A firm with a well-managed supply chain can obtain more benefits from supply chain involvement and become more competitive in NPD. Finally, we controlled for industry and country effects to reduce sample heterogeneity. Two dummies, electronics and machinery, were created to capture industry effects, with transportation as the baseline group. For country effects, we created two dummies for Europe- and Asia-based firms, with U.S.-based firms as the baseline. The descriptive statistics of the variables are presented in Table 2.

\section{$======$ Insert Table 2 about here $======$}

\section{Analyses and results}

\subsection{Reliability and validity}

Following the two-step method recommended by Narasimhan and Jayaram (1998), we first conducted exploratory factor analysis (EFA) and then calculated Cronbach's alpha and composite reliability (CR) to assess the reliability of the scales. We used principal component analysis for EFA and rotated the factors using varimax rotation with Kaiser normalization. The KMO value was 0.766 , and the result of Bartlett's test of sphericity was significant $(p<0.000)$, indicating sampling adequacy for EFA. The results in Table 3 showed five factors with eigenvalues greater than 1.0, which explained $62.135 \%$ of the total variance. All of the items had higher loadings $(>0.50)$ on the constructs that they were designed to measure, and lower loadings on others. The EFA results suggested acceptable unidimensionality of our operationalization. Both the Cronbach's alpha and composite reliability (CR) for all of the constructs were above the suggested cutoff of 0.70 . Thus, the scales were reliable.

$======$ Insert Table 3 about here======

Next, convergent and discriminant validity were tested with confirmatory factor analysis (CFA). We used CFA to estimate the measurement model, where items were linked to the corresponding constructs based on theory. At this stage, all covariance among constructs were freely estimated. The fit indices of the model (Chi-square $(160)=304.39$, RMSEA=0.051, NNFI=0.95, CFI=0.96, Standardized RMR=0.050) were acceptable (Hu and Bentler, 1999). The factor loadings were all greater than or near 0.50 , and all of the t-values exceeded 2.0. The results supported convergent validity. 
In assessing discriminant validity, we conducted chi-square difference tests. We compared two models: (a) a model in which the covariance between a pair of constructs was constrained at 1.0 and (b) a model in which the covariance between constructs was freely estimated. The chi-square differences in a series of models were examined, and we found that all of them were significant at the 0.001 level. The results indicated the distinctiveness of each construct, and thus, discriminant validity was supported.

\subsection{Hypotheses testing}

We used hierarchical regression analysis to test the hypotheses. In Model 1, we entered all of the control variables into the regression model. Then, product modularity (PM) and multi-skill employees (ME) were added to Model 2 to examine their main effects on NPD outcomes. In Model 3, we entered the interactions between PM and supplier involvement (SI), ME and SI, PM and customer involvement (CI), and ME and CI to examine the interactions. To reduce multicollinearity, the independent variables were mean-centered before the interaction terms were created. The collinearity diagnostics showed that all of the variance inflation factors were lower than 4.0, well below the threshold suggested by Cohen et al. (2013).

The results are presented in Table 4. Model 1 reveals that team size $(B=-0.120, S E=0.047$, $\mathrm{p}<0.05)$, team expertise $(\mathrm{B}=0.164, \mathrm{SE}=0.066, \mathrm{p}<0.05)$, and demand variability $(\mathrm{B}=0.129$, $\mathrm{SE}=0.043, \mathrm{p}<0.01)$ significantly affected NPD outcomes. Model 2 shows that product modularity $(\mathrm{B}=0.160, \mathrm{SE}=0.048, \mathrm{p}<0.01)$ improved NPD outcomes, supporting H1 but rejecting H2. Model 3 shows that the interactive effects of product modularity and supplier involvement $(\mathrm{B}=0.116, \mathrm{SE}=0.047, \mathrm{p}<0.01)$, multi-skill employees, and supplier involvement $(B=0.140, S E=0.060, p<0.05)$ on NPD outcomes were significant and positive. Thus, H3a and H4a were supported. The interactive effect of multi-skill employees and customer involvement on NPD outcomes was significantly negative $(B=-0.171, S E=0.060, p<0.05)$, while that of product modularity and customer involvement was not significant. Hence, H3b and H4b were not supported. The results of the hypotheses tests are summarized in Table 5.

To demonstrate the interaction effects, we plotted the effects of PM on NPD outcomes at high (plus one standard deviation) and low (minus one standard deviation) values of SI, and the effects of ME on NPD outcomes at high and low levels of SI and CI (Aiken et al., 1991). As shown in Figure 2, we found that at a high level of SI, the effect of PM on NPD outcomes was positive and significant $(\mathrm{B}=0.276, \mathrm{SE}=0.086, \mathrm{p}<0.01)$, and that at a lovel of SI, the effect was not significant. Second, the effect of ME on NPD outcomes was positive and significant at a high level of $\mathrm{SI}(\mathrm{B}=0.226, \mathrm{SE}=0.108, \mathrm{p}<0.05)$, but not significant at a low level 
of SI. Finally, the effect of ME on NPD outcomes was not significant at a high level of CI but was significant at a low level of $C I(B=0.263, S E=0.102, p<0.05)$. These results reinforced those of our test of interactions.

======Insert Table 4-5 and Figure 2 about here======

\section{Discussion}

Our study shows that product modularity is positively related to NPD outcomes and that multiskill employees do not have a significant impact. As we match modular designs and supply chain involvement to examine the moderating effects, our findings suggest that supplier involvement and product modularity/multi-skill employees influence NPD outcomes synergistically, while customer involvement and multi-skill employees are substitutable.

Our findings demonstrate independent effects of modular designs. We find a positive impact of product modularity on NPD outcomes, which is consistent with previous findings (e.g., Danese, 2013, Jacobs et al., 2007, Lau et al., 2010a, Antonio et al., 2007, Vickery et al., 2016), while multi-skill employees do not have a significant influence. Interestingly, modular applications in product and human resource architecture show diverging effects. An explanation could be the difference between products and people. Product modularity breaks down a complex product system into independent modules and establishes standardized interfaces and architecture (Baldwin and Clark, 1997). Firms can reap benefits from decoupling and the standardization of product architecture by reducing complex interactions. However, the decoupling of employees as modules results in a low level of interaction and communication. This limitation offsets the advantage of being able to flexibly organize and easily deploy multiskill employees to different NPD tasks.

The results for the moderating effects are interesting. First, product modularity and supplier involvement are synergistic for NPD outcomes. Product modularity emphasizes the design of standardized components and product architecture. Its knowledge base is concerned with how products can be decomposed into different parts and how they can be linked with each other through interfaces (Sanchez and Mahoney, 1996). The development of such knowledge requires an in-depth understanding of production systems and product specifications. As suppliers possess component- and architectural-based knowledge and tacit know-how about materials, technologies, and product specifications, their involvement helps with the management of component and architectural complexity, guides the design process, and facilitates finding solutions for the best modular product designs (Cabigiosu and Camuffo, 2017, Wu and Ragatz, 2009, Knudsen, 2007). Because suppliers share common knowledge 
about specific details of product design, firms can easily understand that without extensive direct and on-going communication with the suppliers, the efficiency of modular design is low (Hao et al., 2017). In this way, supplier involvement would be better aligned with the role of product modularity.

Second, supplier involvement positively moderates the relationship between multi-skill employees and NPD outcomes. Multi-skill employees are more capable of communicating with suppliers, absorbing specialized knowledge, and applying it to various NPD tasks. For example, multi-skill employees who simultaneously have procurement and product design experience can conveniently communicate with the supplier at low coordination costs. It is also easy for them to learn from suppliers at low learning costs. Moreover, because suppliers have product architectural and component-based knowledge, they will be more aware of the best architectural design for the focal firm in terms of product and human resources. Their involvement will thus support decision-making regarding the organization of employees for different NPD tasks and teams.

Third, we find no significant interaction between product modularity and customer involvement, which is inconsistent with the findings of Tu et al. (2004). This finding indicates that customer knowledge does not benefit modular product design. Compared with supplier knowledge, customer knowledge is less specialized and is not architectural (Mikkola, 2003, Wu and Ragatz, 2009). For instance, customers' demand for or feedback on a specific product does not directly contribute to improving product platforms or creating better modules. Moreover, as markets are experiencing increasingly diverse and heterogeneous customer demands, key customers might bring only short-term and limited demand information (Knudsen, 2007) that does not benefit the implementation of product modularity. Hence, customer involvement does not occur because customers' knowledge and ability do not apply to product modularity.

Fourth, we found a substitutable relationship between multi-skill employees and customer involvement on NPD outcomes, which means that when human resources are designed using a modular approach, a high level of coupling with customers leads to decreased performance. Consistent with the mirroring hypothesis, multi-skill employees become more important in NPD tasks when there is a low level of customer involvement (Cabigiosu and Camuffo, 2012, MacCormack et al., 2012, Hao et al., 2017). Market-oriented information from customers can be biased and may not reflect customer demands as a whole (Knudsen, 2007); thus, applying knowledge from customers to assigning tasks and forming teams may not lead to the development of highly successful products. In addition, when customers are heavily involved 
in NPD, team members need to interact with them extensively to understand their needs and listen to their suggestions. Under these circumstances, multi-skill employees will be closely coupled with the customer. Frequent interactions with customers may hamper the advantages from decoupling among employees and the flexible configurations of NPD teams.

The theoretical contributions of our findings are twofold. First, our findings enrich the concept of modularity. While modularity has been applied in the organizational, supply chain, and innovation literature (Gualandris and Kalchschmidt, 2013, Patel and Jayaram, 2014, Hoetker et al., 2007, Lau et al., 2010b), few studies have explored it from the perspective of human resource management. The incorporation of multi-skill employees and product modularity in this framework increases our understanding of the role of modularity in designing product architecture and performing corresponding tasks.

Second, our findings contribute to the debate about the mirroring hypothesis. We extend the conventional approach that only investigates the mirroring issue between product and organizational modularity (Baldwin, 2007, Caridi et al., 2012, Davies and Joglekar, 2013). We incorporate multi-skill employees as modular designs in human resource management and examine whether the mirror holds given alignment with the supplier and customer involvement. Thus, different types of modular designs and supply chain involvement influence the mirroring relationship in different ways, which indicates that different mechanisms may exist under the mirroring hypothesis. Our findings mainly support the knowledge-based view and suggest that the mirroring hypothesis should emphasize the role of knowledge. We imply that the role of knowledge is critical to understanding different effects and mechanisms. If supply chain designs offer architectural and component-specific knowledge to develop better modular designs, a high level of interaction between supply chain partners will trigger learning effects and improve the effect of modularity. However, if supply chain partners do not possess specialized knowledge for better module designs, close involvement may constrain modular designs, increase coordination costs, and decrease performance. Thus, simple statements such as "modular designs should be aligned with loose supply chain relationships, while integral designs go along with closely integrated supply chains" are wrong to a large extent.

Our findings offer several managerial implications. First, modular designs and supply chain involvement are closely related. When designing a modular product or human resource architecture, managers should take account of supply chain relationships and estimate tradeoffs. Second, managers need to be aware of the difference between product modularity and multiskill employees. The modular designs of product and human resources are different, as people rely on intensive interactions to create new knowledge. Training multi-skill employees may 
reduce interactions among team members and offset its advantages. Third, managers should be wise when involving suppliers and customers in NPD. Suppliers' specialized knowledge (e.g., product architecture, component, interfaces) supports the design of modular systems (e.g., product modularity and multi-skill employees). Because customer knowledge is not specific or specialized, it is ineffective in product modularity and may hamper the effect of multi-skill employees. Firms may choose alternative strategies that link modular designs and supply chain relationships. In summary, there is no one-to-one mapping strategy in product, organization, and supply chain design. Managers should adopt a holistic perspective to consider different factors when designing strategies for NPD.

\section{Conclusions, limitations, and future research}

This study aims to understand the relationships among modular designs, supply chain involvement, and NPD outcomes. Drawing on the literature about modularity and the debate around the mirroring hypothesis, we investigate the impact of two types of modular designs (i.e., product modularity and multi-skill employees) on NPD outcomes and test the moderating roles of supply chain involvement. We find that product modularity significantly improves NPD outcomes and that supplier involvement positively moderates the relationship between product modularity/multi-skill employees and NPD outcomes. Customer involvement negatively moderates the relationship between multi-skill employees and NPD outcomes. The findings provide evidence that supplier and customer involvement play different roles in the relationships between modular designs and NPD outcomes.

This study contributes to the literature by enriching the conceptualization of modularity and examining the mirroring hypothesis from a broader perspective. Specifically, it identifies multi-skill employees as modular design in human resource management and discusses the impact on NPD successes compared with product modularity. This study also provides some original insights into the complex relationship between modular designs and supply chain involvement. The knowledge-based view is the key to understanding when there are synergistic or tradeoff effects.

While this study makes significant theoretical and practical contributions, it has limitations that open avenues for future research. First, this study focuses on product modularity and multiskill employees. Researchers may argue that the modularity principle can also be applied to process designs (Tu et al., 2004, Mikkola and Skjott-Larsen, 2004). It will be fruitful for future research to examine the effects of product, process, and human resource modular designs on NPD outcomes. Second, the inter-relationship between modular designs and supply chain 
involvement could be contingent (Furlan et al., 2014, Vickery et al., 2016). Future studies could consider more moderators, such as power, trust, and dependence, as the mirroring hypothesis may or may not hold under different contingencies. Third, we use cross-sectional data that cannot reflect causal effects of modularity on NPD outcomes. As modularity can be applied as a long-term strategy, future studies can use longitudinal data to further examine these relationships. 


\section{Appendix Measurement items}

\begin{tabular}{|c|c|c|}
\hline Measurement & Loading $^{\mathrm{d}}$ & T-value \\
\hline \multicolumn{3}{|l|}{ Product modularity $\left(\mathrm{a}^{\mathrm{a}}=0.74, \mathrm{CR}^{\mathrm{b}}=0.75\right)$ Respondents $^{\mathrm{c}}: \mathrm{IM}, \mathrm{PD}, \mathrm{PE}$} \\
\hline $\begin{array}{l}\text { PM1: Our products are modularly designed, so they can be rapidly built by } \\
\text { assembling modules. }\end{array}$ & 0.68 & 11.49 \\
\hline $\begin{array}{l}\text { PM2: We have defined product platforms as a basis for future product variety and } \\
\text { options. }\end{array}$ & 0.57 & 9.66 \\
\hline PM3: Our products are designed to use many common modules. & 0.86 & 14.36 \\
\hline $\begin{array}{l}\text { PM4 } 4^{e} \text { : When we make two products that differ by only a specific feature, they } \\
\text { generally require only one different subassembly/component. (Reversed) }\end{array}$ & - & - \\
\hline \multicolumn{3}{|l|}{ Multi-skill employees $(\mathrm{a}=0.84, \mathrm{CR}=0.83)$ Respondents: $\mathrm{HR}, \mathrm{SP}, \mathrm{PS}$} \\
\hline ME1: Our employees receive training to perform multiple tasks. & 0.88 & 18.47 \\
\hline ME2: Employees at this plant learn how to perform a variety of tasks. & 0.90 & 18.82 \\
\hline $\begin{array}{l}\text { ME3: Employees are cross-trained at this plant, so that they can fill in for others if } \\
\text { necessary. }\end{array}$ & 0.63 & 11.95 \\
\hline ME4: At this plant, each employee only learns how to do one job. (Reversed) & 0.48 & 8.69 \\
\hline \multicolumn{3}{|l|}{ NPD outcomes $(\mathrm{a}=0.71, \mathrm{CR}=0.71)$ Respondents: $\mathrm{PD}$} \\
\hline NPD1: Customer satisfaction & 0.61 & 10.07 \\
\hline NPD2: Return on in vestment & 0.66 & 10.99 \\
\hline NPD3: Time to market & 0.62 & 10.33 \\
\hline NPD4: Ease of manufacturing & 0.55 & 9.02 \\
\hline NPD5: Product conformance quality & 0.44 & 7.09 \\
\hline \multicolumn{3}{|l|}{ Supplier involvement $(\mathrm{a}=0.81, \mathrm{CR}=0.82)$ Respondents: $\mathrm{PD}$} \\
\hline SI1: Suppliers were involved early in the design efforts, in this project & 0.80 & 15.73 \\
\hline SI2: We partnered with suppliers for the design of this product. & 0.78 & 15.17 \\
\hline SI3: Suppliers were frequently consulted about the design of this product. & 0.68 & 12.75 \\
\hline SI4: Suppliers were an integral part of the design effort. & 0.65 & 11.88 \\
\hline $\begin{array}{l}\text { SI5 }{ }^{\text {e: }} \text { Suppliers were selected after the design for this product was completed. } \\
\text { (Reversed) }\end{array}$ & - & - \\
\hline \multicolumn{3}{|l|}{ Customer involvement $(\mathrm{a}=0.83, \mathrm{CR}=0.85)$ Respondents: $\mathrm{PD}$} \\
\hline CI1: We consulted customers early in the design efforts for this product. & 0.78 & 15.21 \\
\hline CI2: We partnered with suppliers for the design of this product. & 0.70 & 13.36 \\
\hline CI3: Customers were frequently consulted about the design of this product. & 0.66 & 12.20 \\
\hline CI4: Customers were an integral part of the design effort for this project. & 0.82 & 16.51 \\
\hline $\begin{array}{l}\text { CI5 } 5^{\text {e }} \text { Customers became involved in this project only after the design was } \\
\text { completed }\end{array}$ & - & - \\
\hline
\end{tabular}

Team size, Respondents: PD

The total number of individuals involved in the project

Team expertise, Respondents: PD

Percent of team members with strong technical expertise.

Project priority, Respondents: PD

Other projects took a back seat to this project because of its importance.

Product size, Respondents: PD

How many parts are required to make one unit?

Manufacturing involvement, Respondents: PD

Manufacturing is involved at the early stages of new product development.

Continuous improvement, Respondents: PE, SP, PS

We strive to continually improve all aspects of products and processes rather than taking a static approach.

Demand variability, Respondents: PD, PE, PS

The needs and wants of our customers are changing very fast.

Supply chain management competence, Respondents: PM, QM, PS

How do your plant's supply chain management compare to its competition in your industry, on a global basis?

Firm size, Respondents: AC 
Number of hourly and salaried personnel employed

${ }^{\mathrm{a}}$ Cronbach's alpha ${ }^{\mathrm{b}}$ Composite reliability

c IM: Inventory Manager; PD: Member of product development; PE: Process engineer; HR: Human resources manager; SP: Supervisor; PS: Plant Superintendent; AC: Plant accounting manager.

${ }^{\mathrm{d}} \mathrm{CFA}$ results ${ }^{\mathrm{e}}$ Item dropped after CFA

\section{References}

Ahmad, O. and Schroeder, R. G. (2003), The impact of human resource management practices on operational performance: Recognizing country and industry differences. Journal of Operations Management, Vol. 21 No. 1, pp. 19-43.

Ahmad, S., Schroeder, R. G. and Mallick, D. N. (2010), The relationship among modularity, functional coordination, and mass customization. European Journal of Innovation Management, Vol. 13 No. 1, pp. 46-61.

Aiken, L. S., West, S. G. and Reno, R. R. (1991), Multiple regression: Testing and interpreting interactions, Sage, Newbury Park, CA.

Akgün, A. E., Dayan, M. and Di Benedetto, A. (2008), New product development team intelligence: Antecedents and consequences. Information \& Management, Vol. 45 No. 4, pp. 221-226.

Antonio, K. L., Yam, R. C. and Tang, E. (2007), The impacts of product modularity on competitive capabilities and performance: An empirical study. International Journal of Production Economics, Vol. 105 No. 1, pp. 1-20.

Appelbaum, E., Bailey, T., Berg, P. B., Kalleberg, A. L. and Bailey, T. A. (2000), Manufacturing advantage: Why high-performance work systems pay off, Cornell University Press.

Argyres, N. S. (1999), The impact of information technology on coordination: Evidence from the b-2 "stealth" bomber. Organization Science, Vol. 10 No. 2, pp. 162-180.

Atkinson, J. (1985), Flexibility, uncertainty and manpower management, Institute of Manpower Studies Brighton, Brighton.

Baldwin, C. Y. (2007), Where do transactions come from? Modularity, transactions, and the boundaries of firms. Industrial and Corporate Change, Vol. 17 No. 1, pp. 155-195.

Baldwin, C. Y. and Clark, K. B. (1997), Managing in an age of modularity. Harvard business review, Vol. 75 No. 5, pp. 84-93.

Baldwin, C. Y. and Clark, K. B. (2000), Design rules: The power of modularity, MIT press.

Barz, C. and Kolisch, R. (2014), Hierarchical multi-skill resource assignment in the telecommunications industry. Production and Operations Management, Vol. 23 No. 3, pp. 489-503.

Batt, R. and Doellgast, V. (2005), Groups, teams, and the division of labor, Oxford University Press, London.

Boxall, P. and Steeneveld, M. (1999), Human resource strategy and competitive advantage: A longitudinal study of engineering consultancies. Journal of Management Studies, Vol. 36 No. 4, pp. 443-463.

Brusoni, S. (2016), The limits to specialization: problem solving and coordination in 'modular networks'. Organization Studies, Vol. 26 No. 12, pp. 1885-1907. 
Brusoni, S., Prencipe, A. and Pavitt, K. (2001), Knowledge specialization, organizational coupling, and the boundaries of the firm: Why do firms know more than they make?. Administrative Science Quarterly, Vol. 46 No. 4, pp.

Cabigiosu, A. and Camuffo, A. (2012), Beyond the "mirroring" hypothesis: Product modularity and interorganizational relations in the air conditioning industry. Organization Science, Vol. 23 No. 3, pp. 686-703.

Cabigiosu, A. and Camuffo, A. (2017), Measuring modularity: engineering and management effects of different approaches. IEEE Transactions on Engineering Management, Vol. 64 No. 1, pp. 103-114.

Cabigiosu, A., Zirpoli, F. and Camuffo, A. (2013), Modularity, interfaces definition and the integration of external sources of innovation in the automotive industry. Research Policy, Vol. 42 No. 3, pp. 662-675.

Campagnolo, D. and Camuffo, A. (2009), The concept of modularity in management studies: A literature review. International Journal of Management Reviews, Vol. 12 No. 3, pp. 259-283.

Camps, J., Oltra, V., Aldás-Manzano, J., Buenaventura-Vera, G. and Torres-Carballo, F. (2016), Individual performance in turbulent environments: The role of organizational learning capability and employee flexibility. Human Resource Management, Vol. 55 No. 3, pp. 363-383.

Caridi, M., Pero, M. and Sianesi, A. (2012), Linking product modularity and innovativeness to supply chain management in the Italian furniture industry. International Journal of Production Economics, Vol. 136 No. 1, pp. 207-217.

Chang, S. 2007. The impact offlexibility-enhancing human resource management practices on firm Adaptability: The mediating role of absorptive capacity. Doctor of Philosophy, The Hong Kong University of Science and Technology.

Cheng, L.-C. (2011), Assessing performance of utilizing organizational modularity to manage supply chains: Evidence in the US manufacturing sector. International Journal of Production Economics, Vol. 131 No. 2, pp. 736-746.

Cohen, J., Cohen, P., West, S. G. and Aiken, L. S. (2013), Applied multiple regression/correlation analysis for the behavioral sciences, Routledge.

Colfer, L. J. 2007. The mirroring hypothesis: Theory and evidence on the correspondence between the structure of products and organizations. In: School, H. B. (ed.) Working paper. Boston.

Colfer, L. J. and Baldwin, C. Y. (2016), The mirroring hypothesis: theory, evidence, and exceptions. Industrial and Corporate Change, Vol. 25 No. 5, pp. 709-738.

Cordery, J. L., Mueller, W. S. and Smith, L. M. (1991), Attitudinal and behavioral effects of autonomous group working: A longitudinal field study. Academy of Management Journal, Vol. 34 No. 2, pp. 464-476.

Craighead, C. W., Ketchen, D. J., Dunn, K. S. and Hult, G. T. M. (2011), Addressing common method variance: Guidelines for survey research on information technology, operations, and supply chain management. IEEE Transactions on Engineering Management, Vol. 58 No. 3, pp. 578-588. 
Danese, P. (2013), Supplier integration and company performance: A configurational view. Omega, Vol. 41 No. 6, pp. 1029-1041.

Danese, P. and Filippini, R. (2010), Modularity and the impact on new product development time performance. International Journal of Operations \& Production Management, Vol. 30 No. 11, pp. 1191-1209.

Danese, P. and Filippini, R. (2013), Direct and mediated effects of product modularity on development time and product performance. IEEE Transactions on Engineering Management, Vol. 60 No. 2, pp. 260-271.

Davies, J. and Joglekar, N. (2013), Supply chain integration, product modularity, and market valuation: Evidence from the solar energy industry. Production and Operations Management, Vol. 22 No. 6, pp. 1494-1508.

De Blok, C., Meijboom, B., Luijkx, K. and Schols, J. (2013), The human dimension of modular care provision: Opportunities for personalization and customization. International Journal of Production Economics, Vol. 142 No. 1, pp. 16-26.

De Toni, A. and Nassimbeni, G. (2003), Small and medium district enterprises and the new product development challenge: Evidence from Italian eyewear district. International Journal of Operations \& Production Management, Vol. 23 No. 6, pp. 678-697.

Edmondson, A. C. and Nembhard, I. M. (2009), Product development and learning in project teams: The challenges are the benefits. Journal of Product Innovation Management, Vol. 26 No. 2, pp. 123-138.

Ernst, D. (2005), Limits to modularity: Reflections on recent developments in chip design. Industry \& Innovation, Vol. 12 No. 3, pp. 303-335.

Ethiraj, S. K., Levinthal, D. and Roy, R. R. (2008), The dual role of modularity: Innovation and imitation. Management Science, Vol. 54 No. 5, pp. 939-955.

Fine, C. H., Golany, B. and Naseraldin, H. (2005), Modeling tradeoffs in three-dimensional concurrent engineering: A goal programming approach. Journal of Operations Management, Vol. 23 No. 3, pp. 389-403.

Fixson, S. K. (2007), Modularity and commonality research: Past developments and future opportunities. Concurrent Engineering, Vol. 15 No. 2, pp. 85-111.

Fixson, S. K. and Park, J. K. (2008), The power of integrality: Linkages between product architecture, innovation, and industry structure. Research Policy, Vol. 37 No. 8, pp. 1296-1316.

Furlan, A., Cabigiosu, A. and Camuffo, A. (2014), When the mirror gets misted up: Modularity and technological change. Strategic Management Journal, Vol. 35 No. 6, pp. 789-807.

Gratton, L. and Ghoshal, S. (2005), Beyond best practice. MIT Sloan Management Review, Vol. 46 No. 3, pp. 49-57.

Gualandris, J. and Kalchschmidt, M. (2013), Product and process modularity: Improving flexibility and reducing supplier failure risk. International Journal of Production Research, Vol. 51 No. 19, pp. 5757-5770.

Hallgren, M. and Olhager, J. (2009), Flexibility configurations: Empirical analysis of volume and product mix flexibility. Omega, Vol. 37 No. 4, pp. 746-756. 
Hao, B., Feng, Y. and Frigant, V. (2017), Rethinking the 'mirroring'hypothesis: Implications for technological modularity, tacit coordination, and radical innovation. $R \& D$ Management, Vol. 47 No. 1, pp. 3-16.

Heim, G. R., Mallick, D. N. and Peng, X. S. (2012), Antecedents and consequences of new product development practices and software tools: An exploratory study. IEEE Transactions on Engineering Management, Vol. 59 No. 3, pp. 428-442.

Heim, G. R. and Peng, D. X. (2010), The impact of information technology use on plant structure, practices, and performance: An exploratory study. Journal of Operations Management, Vol. 28 No. 2, pp. 144-162.

Hoetker, G. (2006), Do modular products lead to modular organizations?. Strategic Management Journal, Vol. 27 No. 6, pp. 501-518.

Hoetker, G., Swaminathan, A. and Mitchell, W. (2007), Modularity and the impact of buyersupplier relationships on the survival of suppliers. Management Science, Vol. 53 No. 2, pp. 178-191.

Hofman, E., Halman, J. I. M. and Song, M. (2017), When to use loose or tight alliance networks for innovation? Empirical evidence. Journal of Product Innovation Management, Vol. 34 No. 1, pp. 81-100.

Hu, L. T. and Bentler, P. M. (1999), Cutoff criteria for fit indexes in covariance structure analysis: Conventional criteria versus new alternatives. Structural Equation Modeling: A Multidisciplinary Journal, Vol. 6 No. 1, pp. 1-55.

Huo, B. F., Ye, Y. X., Zhao, X. D. and Shou, Y. Y. (2016), The impact of human capital on supply chain integration and competitive performance. International Journal of Production Economics, Vol. 178 No., pp. 132-143.

Jacobs, M., Vickery, S. K. and Droge, C. (2007), The effects of product modularity on competitive performance: Do integration strategies mediate the relationship?. International Journal of Operations \& Production Management, Vol. 27 No. 9-10, pp. 1046-1068.

Jansen, J. J., Van Den Bosch, F. A. and Volberda, H. W. (2005), Managing potential and realized absorptive capacity: How do organizational antecedents matter?. Academy of Management Journal, Vol. 48 No. 6, pp. 999-1015.

Kapoor, R. (2013), Persistence of integration in the face of specialization: How firms navigated the winds of disintegration and shaped the architecture of the semiconductor industry. Organization Science, Vol. 24 No. 4, pp. 1195-1213.

Kim, S. and Anand, J. J. (2018), Knowledge complexity and the performance of inter-unit knowledge replication structures. Strategic Management Journal, Vol. 39 No., pp. 1959-1989.

Knudsen, M. P. (2007), The relative importance of interfirm relationships and knowledge transfer for new product development success. Journal of Product Innovation Management, Vol. 24 No. 2, pp. 117-138.

Kumar, A. and Motwani, J. (1995), A methodology for assessing time-based competitive advantage of manufacturing firms. International Journal of Operations \& Production Management, Vol. 15 No. 2, pp. 36-53. 
Lau, A. and Yam, R. (2005), A case study of product modularization on supply chain design and coordination in Hong Kong and China. Journal of Manufacturing Technology Management, Vol. 16 No. 4, pp. 432-446.

Lau, A. K., Tang, E. and Yam, R. (2010a), Effects of supplier and customer integration on product innovation and performance: Empirical evidence in Hong Kong manufacturers. Journal of Product Innovation Management, Vol. 27 No. 5, pp. 761-777.

Lau, A. K. W. (2011a), Supplier and customer involvement on new product performance Contextual factors and an empirical test from manufacturer perspective. Industrial Management \& Data Systems, Vol. 111 No. 5-6, pp. 910-942.

Lau, A. K. W. (2011b), Supplier and customer involvement on new product performance: Contextual factors and an empirical test from manufacturer perspective. Industrial Management \& Data Systems, Vol. 111 No. 5-6, pp. 910-942.

Lau, A. K. W., Yam, R. C. M., Tang, E. P. Y. and Sun, H. Y. (2010b), Factors influencing the relationship between product modularity and supply chain integration. International Journal of Operations \& Production Management, Vol. 30 No. 9-10, pp. 951-977.

Lee, J. and Berente, N. (2012), Digital innovation and the division of innovative labor: Digital controls in the automotive industry. Organization Science, Vol. 23 No. 5, pp. 14281447.

Liao, K., Tu, Q. and Marsillac, E. (2010), The role of modularity and integration in enhancing manufacturing performance. Journal of Manufacturing Technology Management, Vol. 21 No. 7, pp. 818-838.

MacCormack, A., Baldwin, C. and Rusnak, J. (2012), Exploring the duality between product and organizational architectures: A test of the "mirroring" hypothesis. Research Policy, Vol. 41 No. 8, pp. 1309-1324.

MacDuffie, J. P. (2013), Modularity-as-property, modularization-as-process, and 'modularity'as-frame: Lessons from product architecture initiatives in the global automotive industry. Global Strategy Journal, Vol. 3 No. 1, pp. 8-40.

Martinez-Sanchez, A., Vela-Jimenez, M. J., Perez-Perez, M. and de-Luis-Carnicer, P. (2011), The dynamics of labour flexibility: Relationships between employment type and innovativeness. Journal of Management Studies, Vol. 48 No. 4, pp. 715-736.

Mikkola, J. H. (2003), “Modularity, component outsourcing, and inter - firm learning”. $R \& D$ Management, Vol. 33 No. 4, pp. 439-454.

Mikkola, J. H. and Gassmann, O. (2003), Managing modularity of product architectures: Toward an integrated theory. IEEE Transactions on Engineering Management, Vol. 50 No. 2, pp. 204-218.

Mikkola, J. H. and Skjott-Larsen, T. (2004), Supply-chain integration: Implications for mass customization, modularization, and postponement strategies. Production Planning \& Control, Vol. 15 No. 4, pp. 352-361.

Mishra, A. A. and Shah, R. (2009), In union lies strength: Collaborative competence in new product development and its performance effects. Journal of Operations Management, Vol. 27 No. 4, pp. 324-338. 
Narasimhan, R. and Jayaram, J. (1998), Causal linkages in supply chain management: An exploratory study of North American manufacturing firms. Decision Sciences, Vol. 29 No. 3, pp. 579-605.

Nepal, B., Monplaisir, L. and Famuyiwa, O. (2012), Matching product architecture with supply chain design. European Journal of Operational Research, Vol. 216 No. 2, pp. 312-325.

Pashaei, S. and Olhager, J. (2015), Product architecture and supply chain design: A systematic review and research agenda. Supply Chain Management: An International Journal, Vol. 20 No. 1, pp. 98-112.

Patel, P. C. and Jayaram, J. (2014), The antecedents and consequences of product variety in new ventures: An empirical study. Journal of Operations Management, Vol. 32 No. 12, pp. 34-50.

Peng, D. X., Heim, G. R. and Mallick, D. N. (2014), Collaborative Product Development: The Effect of Project Complexity on the Use of Information Technology Tools and New Product Development Practices. Production and Operations Management, Vol. 23 No. 8, pp. 1421-1438.

Peng, D. X., Verghese, A., Shah, R. and Schroeder, R. G. (2013), The relationships between external integration and plant improvement and innovation capabilities: The moderation effect of product clockspeed. Journal of Supply Chain Management, Vol. 49 No. 3, pp. 3-24.

Pero, M., Abdelkafi, N., Sianesi, A. and Blecker, T. (2010), A framework for the alignment of new product development and supply chains. Supply Chain Management: An International Journal, Vol. 15 No. 2, pp. 115-128.

Petersen, K. J., Handfield, R. B. and Ragatz, G. L. (2005), Supplier integration into new product development: Coordinating product, process and supply chain design. Journal of Operations Management, Vol. 23 No. 3, pp. 371-388.

Pil, F. K. and Cohen, S. K. (2006), Modularity: Implications for imitation, innovation, and sustained advantage. Academy of Management Review, Vol. 31 No. 4, pp. 995-1011.

Podsakoff, P. M., MacKenzie, S. B., Lee, J.-Y. and Podsakoff, N. P. (2003), Common method biases in behavioral research: A critical review of the literature and recommended remedies. Journal of Applied Psychology, Vol. 88 No. 5, pp. 879-903.

Priem, R. L. and Swink, M. (2012), A demand-side perspective on supply chain management. Journal of Supply Chain Management, Vol. 48 No. 2, pp. 7-13.

Ro, Y. K., Liker, J. K. and Fixson, S. K. (2007), Modularity as a strategy for supply chain coordination: The case of U.S. Auto. IEEE Transactions on Engineering Management, Vol. 54 No. 1, pp. 172-189.

Salvador, F. (2007), Toward a product system modularity construct: Literature review and reconceptualization. Ieee Transactions on Engineering Management, Vol. 54 No. 2, pp. 219-240.

Salvador, F. and Villena, V. H. (2013), Supplier integration and NPD outcomes: Conditional moderation effects of modular design competence. Journal of Supply Chain Management, Vol. 49 No. 1, pp. 87-113. 
Sanchez, R. and Mahoney, J. T. (1996), Modularity, flexibility, and knowledge management in product and organization design. Strategic Management Journal, Vol. 17 No. S2, pp. 63-76.

Sanderson, S. W. and Uzumeri, M. (1997), Managing product families, Irwin Professional Pub.

Schilling, M. A. (2000), Toward a general modular systems theory and its application to interfirm product modularity. Academy of Management Review, Vol. 25 No. 2, pp. 312334.

Schilling, M. A. and Steensma, H. K. (2001), The use of modular organizational forms: An industry-level analysis. Academy of Management Journal, Vol. 44 No. 6, pp. 11491168.

Schroeder, R. G. and Flynn, B. B. (2002), High performance manufacturing: Global perspectives, John Wiley \& Sons, New York.

Sorkun, M. F. and Furlan, A. (2017), Product and organizational modularity: A contingent view of the mirroring hypothesis. European Management Review, Vol. 14 No. 2, pp. 205-224.

Swan, J., Newell, S., Scarbrough, H. and Hislop, D. (1999), Knowledge management and innovation: Networks and networking. Journal of Knowledge Management, Vol. 3 No. 4, pp. 262-275.

Takeishi, A. (2001), "Bridging inter - and intra - firm boundaries: Management of supplier involvement in automobile product development”. Strategic Management Journal, Vol. 22 No. 5, pp. 403-433.

Tang, F., Mu, J. and Thomas, E. (2015), Who knows what in NPD teams: Communication context, mode, and task contingencies. Journal of Product Innovation Management, Vol. 32 No. 3, pp. 404-423.

Tien-Shang Lee, L. (2008), The effects of team reflexivity and innovativeness on new product development performance. Industrial Management \& Data Systems, Vol. 108 No. 4, pp. 548-569.

Tu, Q., Vonderembse, M. A., Ragu-Nathan, T. S. and Ragu-Nathan, B. (2004), Measuring modularity-based manufacturing practices and their impact on mass customization capability: A customer-driven perspective. Decision Sciences, Vol. 35 No. 2, pp. 147168.

Vickery, S. K., Koufteros, X. and Droge, C. (2013), Does product platform strategy mediate the effects of supply chain integration on performance? A dynamic capabilities perspective. IEEE Transactions on Engineering Management, Vol. 60 No. 4, pp. 750762.

Vickery, S. K., Koufteros, X., Dröge, C. and Calantone, R. (2016), Product Modularity, Process Modularity, and New Product Introduction Performance: Does Complexity Matter?. Production and Operations Management, Vol. 25 No. 4, pp. 751-770.

Wagner, S. M. and Hoegl, M. (2006), Involving suppliers in product development: Insights from R\&D directors and project managers. Industrial Marketing Management, Vol. 35 No. 8, pp. 936-943. 
Wang, S., Li, J., Song, J., Li, Y. and Sherk, M. (2018), Institutional pressures and product modularity: Do supply chain coordination and functional coordination matter?. International Journal of Production Research, Vol. No., pp. 1-14.

Worren, N., Moore, K. and Cardona, P. (2002), Modularity, strategic flexibility, and firm performance: A study of the home appliance industry. Strategic Management Journal, Vol. 23 No. 12, pp. 1123-1140.

Wu, S. J. and Ragatz, G. L. (2009), The role of integrative capabilities in involving suppliers in new product development: A knowledge integration perspective. International Journal of Manufacturing Technology and Management, Vol. 19 No. 1-2, pp. 82-101.

Yin, Y., Kaku, I. and Liu, C. (2014), Product architecture, product development process, system integrator and product global performance. Production Planning \& Control, Vol. 25 No. 3, pp. 203-219.

Zhang, M., Guo, H., Huo, B., Zhao, X. and Huang, J. (2017), Linking supply chain quality integration with mass customization and product modularity. International Journal of Production Economics, Vol. No., pp.

Zhang, M., Zhao, X. D. and Qi, Y. N. (2014), The effects of organizational flatness, coordination, and product modularity on mass customization capability. International Journal of Production Economics, Vol. 158 No., pp. 145-155.

Zirpoli, F. and Camuffo, A. (2009), "Product architecture, inter - firm vertical coordination and knowledge partitioning in the auto industry” . European Management Review, Vol. 6 No. 4, pp. 250-264. 


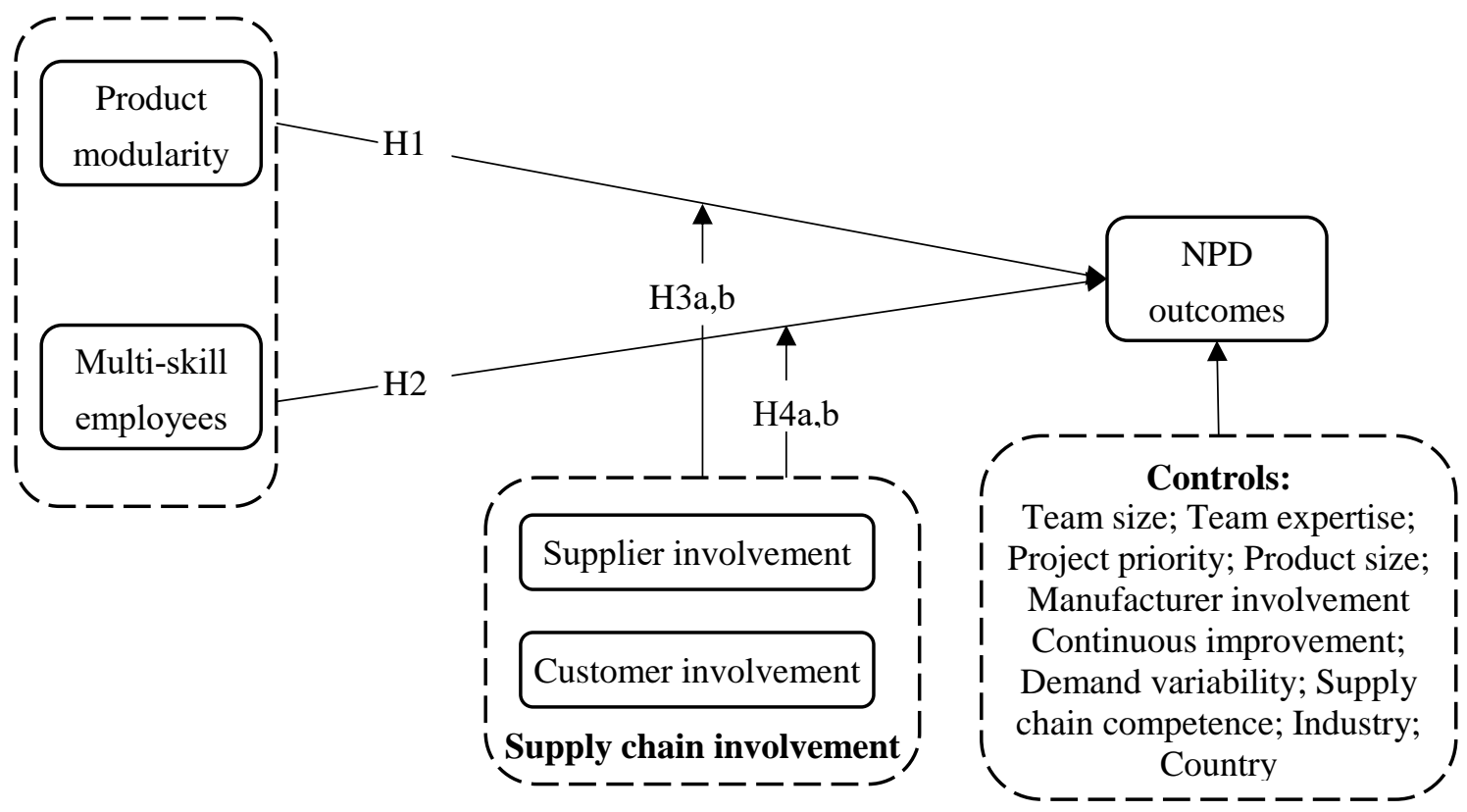

Figure 1. Conceptual model 


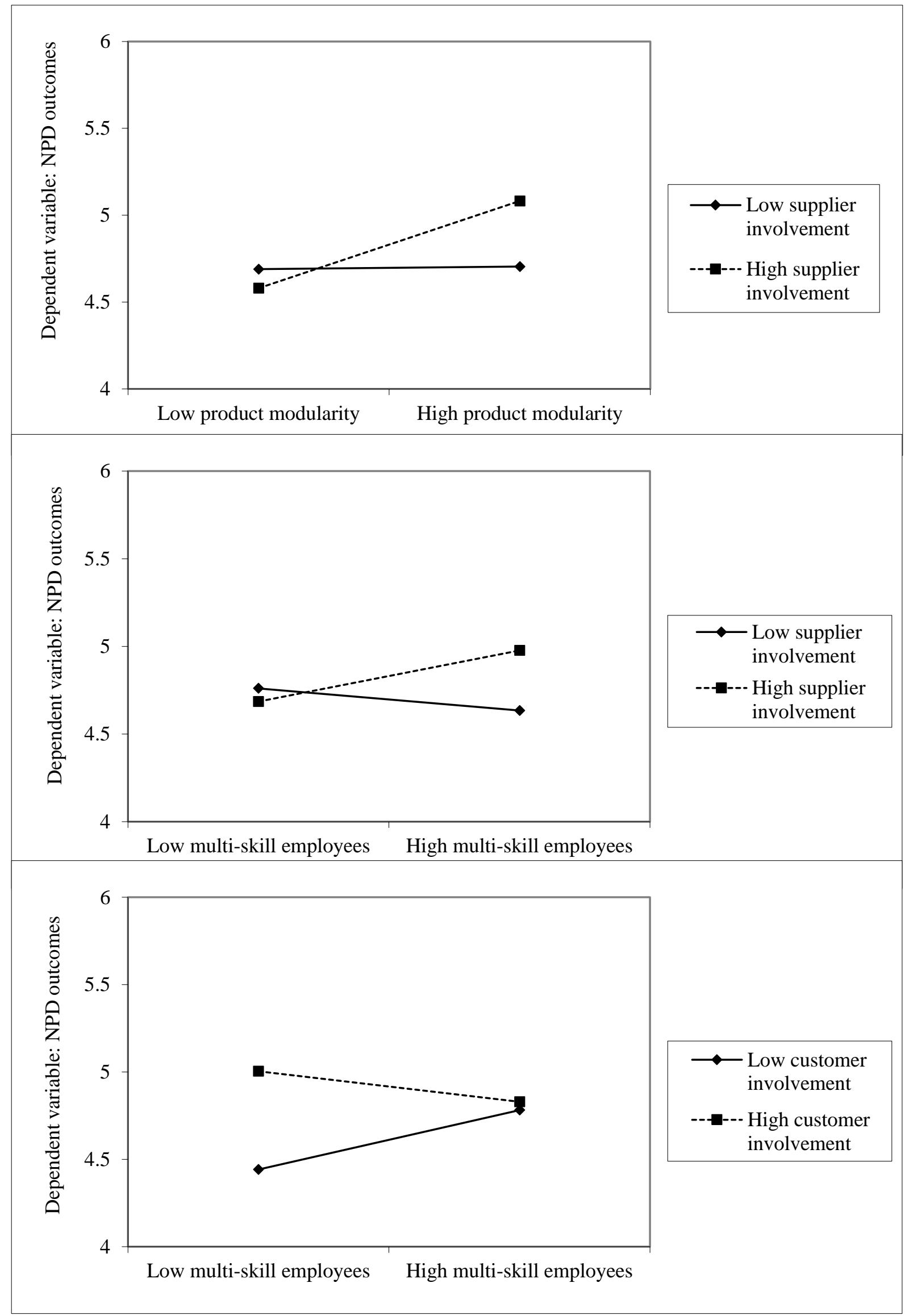

Figure 2. Interaction effects 
Table 1. Sample demographics

\begin{tabular}{lccccc}
\hline Countries & \multicolumn{3}{c}{ Industry } & Population & $\begin{array}{c}\text { Total } \\
\text { sample }\end{array}$ \\
\cline { 2 - 4 } & Machinery & Electronics & Transportation & & sanc \\
Austria & 7 & 10 & 4 & 5143 & 21 \\
China & 16 & 21 & 14 & 218901 & 51 \\
Finland & 6 & 14 & 10 & 6118 & 30 \\
Germany & 13 & 9 & 19 & 48437 & 41 \\
Italy & 10 & 10 & 7 & 96458 & 27 \\
Japan & 12 & 10 & 13 & 75344 & 35 \\
South Korea & 10 & 10 & 11 & 25791 & 31 \\
Spain & 9 & 9 & 10 & 29970 & 28 \\
Sweden & 10 & 7 & 7 & 13190 & 24 \\
United States & 11 & 9 & 9 & 60379 & 29 \\
Total & 104 & 109 & 104 & 579731 & 317 \\
\hline
\end{tabular}

Table 2. Descriptive statistics and correlations

\begin{tabular}{lccccccc}
\hline & Mean & S.D. & 1 & 2 & 3 & 4 & 5 \\
\hline 1 Product modularity & 4.70 & .910 & - & & & & \\
2 Multi-skill employees & 5.30 & .646 & .08 & - & & & \\
3 NPD outcomes & 4.81 & .789 & $.17^{* *}$ & -.02 & - & & \\
4 Supplier involvement & 4.75 & 1.154 & $.22^{* *}$ & .05 & $.19^{* *}$ & - & \\
5 Customer involvement & 4.94 & 1.164 & -.05 & .01 & $.20^{* *}$ & $.43^{* *}$ & - \\
\hline$* * p<0.01$ & & & & & & &
\end{tabular}

Table 3. Exploratory factor analysis

\begin{tabular}{lccccc}
\hline & \multicolumn{5}{c}{ Factor loadings } \\
\cline { 2 - 6 } & $\begin{array}{c}\text { Multi-skill } \\
\text { employees }\end{array}$ & $\begin{array}{c}\text { Customer } \\
\text { involvement }\end{array}$ & $\begin{array}{c}\text { Supplier } \\
\text { involvement }\end{array}$ & $\begin{array}{c}\text { NPD } \\
\text { outcomes }\end{array}$ & $\begin{array}{c}\text { Product } \\
\text { modularity }\end{array}$ \\
\hline PM1 & 0.081 & -0.032 & 0.086 & 0.057 & $\mathbf{0 . 8 0 0}$ \\
PM2 & 0.053 & -0.008 & 0.054 & 0.107 & $\mathbf{0 . 7 4 0}$ \\
PM3 & -0.028 & -0.068 & 0.150 & 0.085 & $\mathbf{0 . 8 4 6}$ \\
ME1 & $\mathbf{0 . 8 3 1}$ & -0.025 & 0.035 & 0.065 & -0.009 \\
ME2 & $\mathbf{0 . 8 7 3}$ & -0.003 & 0.016 & 0.021 & 0.015 \\
ME3 & $\mathbf{0 . 8 3 9}$ & -0.051 & 0.058 & -0.013 & 0.079 \\
ME4 & $\mathbf{0 . 7 4 7}$ & 0.057 & -0.029 & -0.121 & 0.039 \\
NPD1 & -0.101 & -0.052 & 0.204 & $\mathbf{0 . 6 8 7}$ & 0.126 \\
NPD2 & -0.013 & 0.132 & 0.053 & $\mathbf{0 . 7 1 5}$ & 0.072 \\
NPD3 & 0.080 & 0.165 & -0.035 & $\mathbf{0 . 7 3 4}$ & -0.063 \\
NPD4 & -0.034 & 0.033 & 0.013 & $\mathbf{0 . 6 6 4}$ & 0.060 \\
NPD5 & 0.009 & 0.021 & 0.053 & $\mathbf{0 . 5 6 5}$ & 0.072 \\
SI1 & 0.075 & 0.136 & $\mathbf{0 . 8 3 8}$ & 0.055 & 0.050 \\
SI2 & -0.019 & 0.186 & $\mathbf{0 . 8 0 9}$ & 0.048 & 0.083 \\
SI3 & 0.101 & 0.243 & $\mathbf{0 . 7 1 8}$ & 0.049 & 0.089 \\
SI4 & -0.066 & 0.162 & $\mathbf{0 . 7 1 5}$ & 0.125 & 0.118 \\
CI1 & -0.039 & $\mathbf{0 . 8 3 2}$ & 0.093 & 0.083 & 0.024 \\
CI2 & -0.045 & $\mathbf{0 . 7 6 0}$ & 0.237 & 0.053 & -0.036 \\
CI3 & 0.096 & $\mathbf{0 . 7 3 6}$ & 0.201 & 0.076 & -0.014 \\
CI4 & -0.035 & $\mathbf{0 . 8 1 2}$ & 0.196 & 0.100 & -0.105 \\
\hline Eigenvalues & 2.829 & 1.227 & 1.913 & 2.355 & 4.102 \\
Total variance explained & \multicolumn{4}{c}{$62.135 \%$} \\
\hline Bold
\end{tabular}

Bold values refer to item loadings onto a particular factor. 
Table 4. Regression results

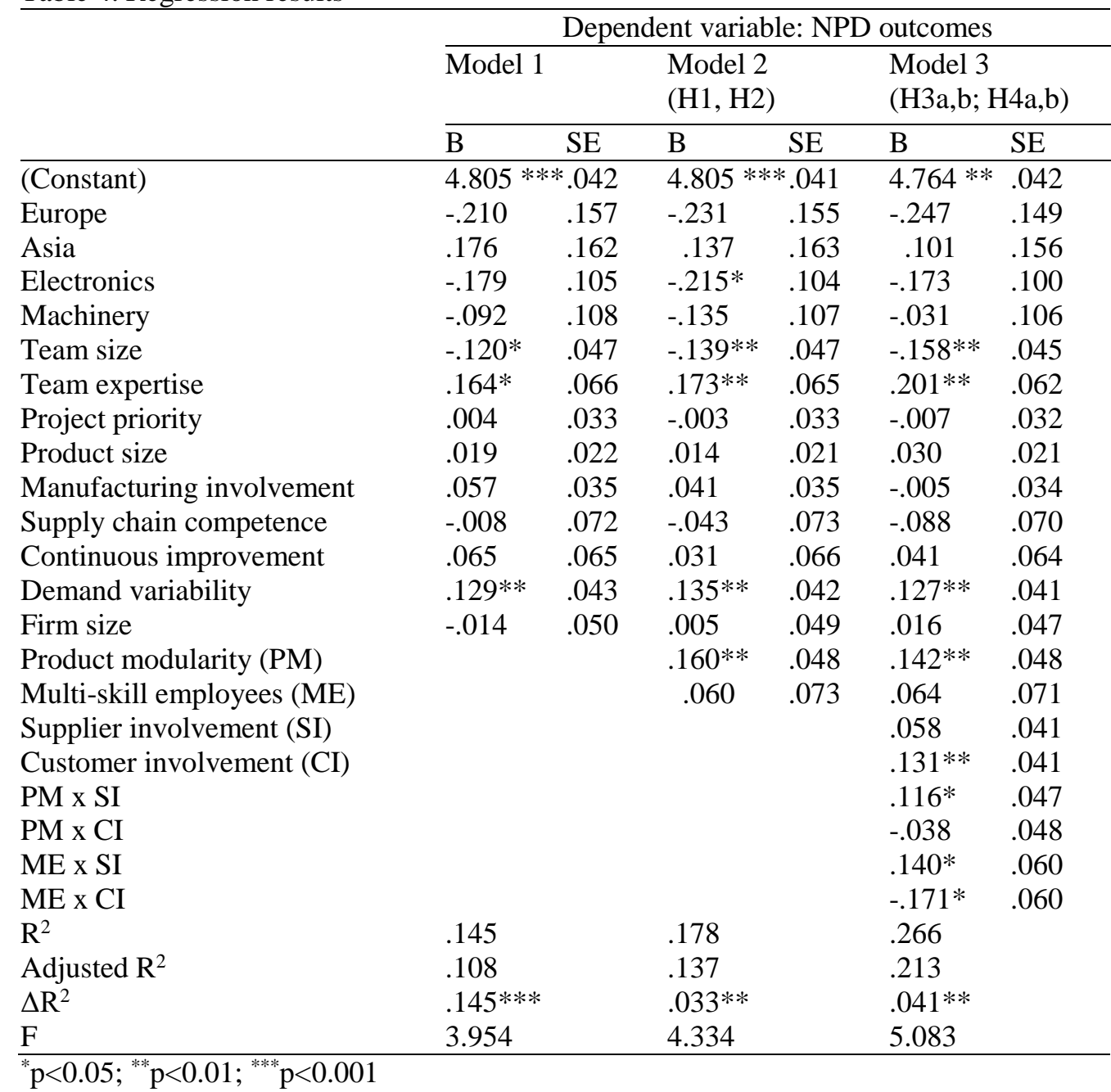

Table 5. Summary of hypothesis test results

\begin{tabular}{ll}
\hline Hypotheses & Result \\
\hline H1: Product modularity $\rightarrow$ NPD outcomes $(+)$ & Supported \\
H2: Multi-skill employees $\rightarrow$ NPD outcomes $(+)$ & Rejected \\
H3a: Product modularity x Supplier involvement $\rightarrow$ NPD outcomes $(+)$ & Supported \\
H3b: Product modularity x Customer involvement $\rightarrow$ NPD outcomes $(+)$ & Rejected \\
H4a: Multi-skill employees x Supplier involvement $\rightarrow$ NPD outcomes $(+)$ & Supported \\
H4b Multi-skill employees x Customer involvement $\rightarrow$ NPD outcomes $(+)$ & Rejected \\
\hline
\end{tabular}

